
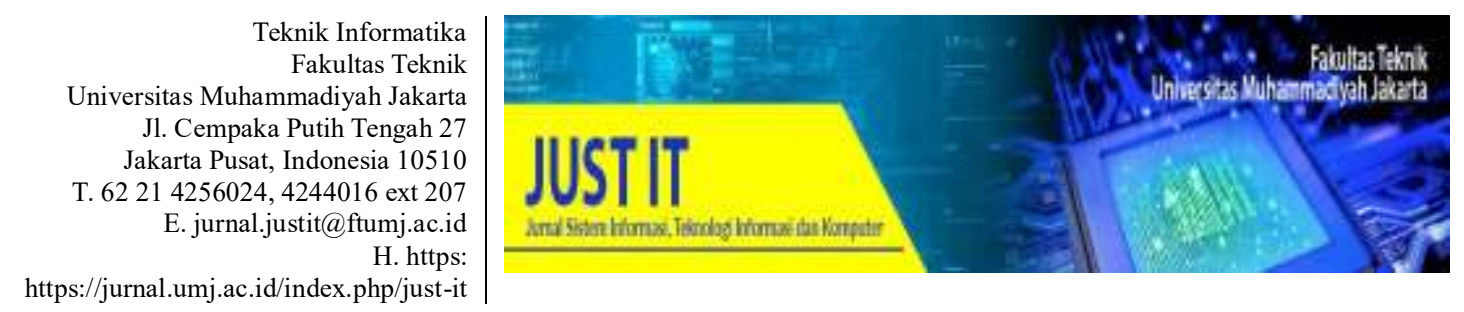

\title{
MENINGKATKAN LITERASI PERBANKAN SYARIAH DENGAN MENGEMBANGKAN APLIKASI EDUKASI BERBASIS ANDROID
}

\author{
Moh Khoirul Anam ${ }^{1}$, Lia Anggraini², \\ 1,2, Program Studi Manajemen Perbankan Syariah, Universitas Muhammadiyah Jakarta \\ m.khoirulanam@umj.ac.id ${ }^{1}$, lia.anggrainitanjung@gmail.com²
}

\begin{abstract}
Abstrak
Pangsa pasar (market share) keuangan syariah secara keseluruhan masih di bawah 5\% dari total market share perbankan nasional. Salah satu penyebabnya adalah konsumen atau masyarakat masih kurangnya pengetahuan, pemahaman dan loyalitas konsumen yang masih rendah terhadap bank syariah. Penelitian ini mengembangkan aplikasi edukasi berbasis android dan menguji efektifitas aplikasi tersebut pada peningkatan pengetahuan karyawan Yayasan Baitul Yataama Fadlan tentang perbankan syariah. Responden menggunakan aplikasi edukasi dan mempelajari konten perbankan syariah selama 2 hari. Sebelum dan sesudah responden menggunakan aplikasi tersebut dilaksanakan survey dengan memberikan berbagai pertanyaan. Survey bertujuan untuk melihat pengetahuan responden sebelum dan sesudah penggunaan aplikasi, apakah terdapat kenaikan yang signifikan. Hasil survey pertama menggunakan kuesioner menunjukkan hasil sebesar $47 \%$. Survey kedua menunjukkan hasil sebesar $67 \%$. Terdapat kenaikan prosentase responden yang menjawab mengetahui perbankan syariah sebesar $20 \%$. Hal ini dapat disimpulkan bahwa Aplikasi edukasi perbankan syariah berpengaruh signifikan dalam meningkatkan pengetahuan responden.
\end{abstract}

Kata Kunci: Literasi Perbankan Syariah, Loyalitas Konsumen, Aplikasi Android

\begin{abstract}
The overall market share of Islamic finance is still below $5 \%$ of the total national banking market share. One reason is consumers or the public is still lack of knowledge, understanding and consumer loyalty that is still low on Islamic banks. This research develops an android-based educational application and tests the effectiveness of the application on improving the knowledge of employees of the Baitul Yataama Fadlan Foundation about Islamic banking. Respondents used educational applications and studied Islamic banking content for 2 days. Before and after the respondents used the application, a survey was conducted by asking various questions. The survey aims to see the knowledge of respondents before and after the use of the application, whether there is a significant increase. The results of the first survey using a questionnaire showed results of $47 \%$. Then a second survey was conducted with a result of $67 \%$. There is an increase in the percentage of respondents who answered knowing of Islamic banking by $20 \%$. It can be concluded that the application of Islamic banking education has a significant effect in increasing the knowledge of the respondents .
\end{abstract}

Keywords: Islamic banking literacy, consumer loyalty, Android applications 


\section{PENDAHULUAN}

Meskipun penduduk Indonesia mayoritas beragama Islam tetapi perbankan syariah masih kalah jauh dengan bank konvensional. Pertumbuhan keuangan syariah belum dapat mengimbangi pertumbuhan keuangan konvensional. Hal ini dapat dilihat dari pangsa pasar (market share) keuangan syariah yang secara keseluruhan masih di bawah 5\% (Septyaningsih, 2018). Kendala yang dihadapi bank syariah diantaranya : 1) masih banyak bank syariah belum memiliki modal yang memadai, 2) lemahnya pemahaman praktisi bank syariah; 3) kurangnya dukungan pemerintah; 4) trust dan minat masyarakat masih rendah (Rusydiana, 2016).

Menurut Rektor UMY, Dr Ir Gunawan Budiyanto MP, hasil sosialisasi kepada masyarakat yang dilakukan oleh perbankan syariah selama 25 tahun ini menunjukkan bahwa pengetahun masyarakat tentangnya masih minim. Selain itu menurutnya, masih banyak pula institusi Islam yang rupanya belum memanfaatkan sistem perbankan syari'ah dengan maksimal. Hal itulah yang menurutnya perlu dicarikan solusinya. Diharapkan setelah 25 tahun berdiri bank syari'ah bisa mencapai sasarannya yaitu menjadi subtitusi sistem perbankan yang kapital dengan perbankan syariah, sehingga menjadi sistem yang berkeadilan (Iskandarsjah, 2017).

Kebanyakan masyarakat memang sudah tahu apa itu bank syariah, tetapi mereka tidak tahu produk-produk yang ditawarkan bank syariah. Masyarakat yang tidak mengetahui produk-produk bank syariah tentunya tidak akan berminat untuk menggunakan jasa bank syariah, karena mereka menganggap bahwa fasilitas penunjang yang diberikan masih kalah dengan fasilitas yang ditawarkan oleh bank konvensional. kecuali orang yang mempunyai kenginan kuat menabung pada bank syariah dikarenakan menghindari unsur riba.

Pemahaman masyarakat tentang bank syariah juga akan mempengaruhi pandangan masyarakat mengenai bank syariah itu sendiri. Secara mudahnya, pandangan masyarakat terhadap bank syariah tergantung dengan apa yang mereka ketahui. Pengetahuan konsumen adalah semua informasi yang dimiliki konsumen mengenai berbagai macam produk dan jasa, serta pengetahuan lainnya yang terkait dengan produk dan jasa tersebut dan informasi yang berhubungan dengan fungsinya sebagai konsumen. Azhar (Azhar Muttaqin, 2017) meneliti 3 aspek pengetahuan produk yaitu: (1). Pengetahuan tentang kualitas produk. (2). Pengetahuan tentang kualitas pelayanan, dan (3). Pengetahuan tentang nilai syariah. Ketiga aspek tersebut berpengaruh signifikan terhadap keputusan menjadi nasabah.

Kalangan masyarakat saat ini sangat familiar mengoperasikan telepon genggam. Merupakan salah satu teknologi yang tidak dapat terlepas dari kehidupan sehari-hari. Selain mudah didapat, telephon genggam juga mudah digunakan kapan saja, dan di mana saja. Layaknya komputer, telephon genggam saat ini dapat diinstal dengan berbagai macam program yang diinginkan. Salah satu sistem operasi yang sangat diminati saat ini adalah Android. Android mempunyai kelebihan di bidang pengembangan aplikasi, dengan sistem open source program Android dapat dibuat oleh siapa saja dengan gratis. Hingga saat ini Android mampu berkembang lebih pesat dari para pesaingnya dari segi sistem maupun aplikasinya. Oleh karena itu banyak aplikasiaplikasi yang diciptakan dengan berbasis Android.

Di seluruh negara Asia Tenggara yang tentunya termasuk Indonesia, Android menguasai lebih dari separuh pangsa pasar. Data tersebut tertuang dalam laporan yang disusun oleh biro marketing bernama Waiwai Marketing. Mereka mengumpulkan data dari Facebook untuk memperkirakan jumlah ponsel yang digunakan di Asia Tenggara. Dari laporan tersebut, Indonesia tercatat sebagai negara di Asia Tenggara yang warganya terbanyak menggunakan Android. Totalnya yakni pengguna 41 juta pengguna atau pangsa pasarnya $94 \%$. Sementara iOS di Indonesia hanya digunakan 2,8 juta pengguna atau $6 \%$ dari banyaknya pengguna android di Indonesia (Rachman; Adi Fida, 2015).

Untuk memudahkan para masyarakat mendapatkan informasi mengenai perbankan syariah, dalam penelitian ini mencoba untuk membuat suatu software yang berisi tentang berbagai informasi tentang perbankan syariah. 
Software akan diuji efektifitasnya dalam meningkatkan pengetahuan masyarakat tentang bank syariah.

\section{LANDASAN TEORI \\ 1. Bank Syariah}

Perbankan syariah atau perbankan Islam (Ghofur, 2018) adalah suatu sistem perbankan yang pelaksanaannya berdasarkan hukum Islam (syariah). Pembentukan sistem ini berdasarkan adanya larangan dalam Agama Islam untuk meminjamkan atau memungut pinjaman dengan mengenakan bunga pinjaman (riba), serta larangan untuk berinvestasi pada usaha-usaha berkategori terlarang (haram). Sistem perbankan konvensional tidak dapat menjamin absennya hal-hal tersebut dalam investasinya, misalnya dalam usaha yang berkaitan dengan produksi makanan atau minuman haram, usaha media atau hiburan yang tidak Islami, dan lain-lain (Supyadillah; Asep, 2013).

\section{Android}

Android merupakan sebuah sistem operasi perangkat mobile berbasis Linux yang mencakup sistem operasi, middleware dan aplikasi. Beberapa pengertian lain dari Android (Supardi; Yanuar, 2015), yaitu:

a. Merupakan platform terbuka (Open Source) bagi para pengembang (Programmer) untuk membuat aplikasi.

b. Merupakan sistem operasi yang dibeli Google Inc. dari Android Inc.

c. Bukan bahasa pemrograman, tetapi hanya menyediakan lingkungan hidup atau run time environment yang disebut DVM (Dalvik Virtual Machine) yang telah dioptimasi untuk alat/device dengan sistem memori yang kecil.

\section{App Thunkable}

App Thunkable adalah sebuah tool untuk membuat aplikasi Android yang berbasis visual block programming, sehingga pengguna bisa membuat aplikasi tanpa melakukan coding. Visual block programming maksudnya adalah dalam penggunaannya user akan melihat, menggunakan, menyusun dan drag-drops "blok" yang merupakan simbolsimbol perintah dan fungsi event handler tertentu dalam membuat aplikasi, dan secara sederhana bisa disebut tanpa menuliskan kode program (Mulyadi, 2013) .

\section{METODE PENELITIAN}

\section{Tempat Penelitian}

Penelitian ini dilaksanakan pada Yayasan Baitul Yataama Fadlan, dengan target tujuan karyawan. Yang nantinya karyawan Yayasan Baitul Yataama Fadlan akan diberikan kuesioner sebelum menggunakan aplikasi dan setelah menggunakan aplikasi.

\section{Metode Pengembangan Aplikasi}

Metode yang digunakan pada perancangan dan pembangunan aplikasi ini adalah metode pengembangan sistem Rapid Application Development (RAD). Metode ini cocok untuk pengembangan aplikasi yang menekankan kecepatan dalam pembuatan aplikasi (Supardi; Yanuar, 2015). Model RAD sesuai untuk menghasilkan sistem perangkat lunak dengan kebutuhan mendesak dan waktu yang singkat dalam penyelesainnya. Jika kebutuhan perangkat lunak dipahami dengan baik dan lingkup perangkat lunak dibatasi dengan baik sehingga tim dapat menyelesaikan pembuatan perangkat lunak dengan waktu yang pendek (Febriani \& Hidayati, 2017).

Dalam fase perencanaan prasyarat, kegiatan yang dilaksanakan sebagai berikut :

o Mencari informasi tentang perbankan syariah

- Mengidentifikasi tujuan aplikasi dan kebutuhan sistem

- Menentukan fitur yang akan dibuat pada aplikasi

- Kebutuhan hardware dan software untuk membangun aplikasi

Pada tahap desain, desain aplikasi yang akan dibangun yang sesuai dengan tujuan penelitian dan masalah yang akan dihadapi.

\section{Metode Pengumpulan data}

Metode pengumpulan data dalam penelitian ini menggunakan kuesioner. Kuesioner ini juga bertujuan untuk mengetahui bagaimana pengetahuan karyawan Yayasan Baitul Yataama Fadlan 
tentang perbankan syariah. Kuesioner akan menghasilkan data seberapa besar pengaruh aplikasi perbankan syariah terhadap meningkatkan pengetahuan karyawan. Untuk melihat perbedaan pengetahuan dilaksanakan dengan membandingkan hasil antara kuesioner pertama dan kuesioner ke dua.

Penelitian dimulai dengan memberikan kuesioner pertama, kemudian responden men download aplikasi. Responden diberikan waktu 2 hari untuk memahami dan mempelajari aplikasi edukasi perbankan syariah. Setelah itu, responden mengisi kuesioner yang ke dua.

\section{Variabel Penelitian}

Variabel bebas dalam penelitian ini adalah aplikasi edukasi perbankan syariah yang berisi pengetahuan perbankan syariah antara lain dasar hukum yang ada di perbankan syariah, simulasi peminjaman KPR, Tabungan, M-Banking dan nanti di tambahkan dengan informasi Call Center

Adapun variabel terikat dalam penelitian ini adalah meningkatkan pengetahuan karyawan Yayasan Baitul Yataama Fadlan tentang perbankan syariah. Pengukuran pengetahuan menggunakan indikator sebagai berikut :

- Meningkatkan pengetahuan responden tentang perbankan syariah

- Mengetahui perkembangan informasi tentang perbankan syariah

- Memahami tentang produk-produk yang ada di perbankan syariah.

- Mengetahui keunggulan di setiap produk perbankan syariah.

\section{Populasi dan Sampel}

Populasi dalam hal ini adalah karyawan Yayasan Baitul Yataama Fadlan. Teknik pengambilan sampel dalam penelitian ini adalah sampel acak sederhana, dimana setiap anggota populasi mempunyai hak yang sama untuk dijadikan sampel dalam penlitian ini (Misbahudin, 2013). Dari seluruh jumlah populasi yang ada dalam penelitian ini akan mengambil 34 responden yang akan dijadikan sampel

\section{Teknik Analisis Data}

Teknik analisis data menggunakan pendekatan statistik deskriptif maupun inferensia. Statistik deskriptif digunakan untuk mendeskripsikan data sampel yang meliputi distribusi frekuensi, grafik, mean (nilai rata-rata hitung), median (nilai rata-rata tengah), modus (nilai yang mempunyai frekuensi paling banyak), Varian (jumlah kuadrat semua deviasi), Standar deviasi (akar kuadrat varians). Statistik inferensia digunakan untuk menguji hipotesis pengaruh aplikasi perbankan syariah terhadap peningkatan pengetahuan karyawan Yayasan Baitul Yataama Fadlan

\section{HASIL DAN PEMBAHASAN}

\section{Aplikasi edukasi Perbankan Syariah}

Aplikasi edukasi perbankan syariah ini dibuat bertujuan untuk meningkatkan pengetahuan masyarakat. dikarnakan saat ini minim sekali pengetahuan masyarakat tentang perbankan syariah sehingga saat ini masih banyak masyarakat yang berpendapat bahwa Bank Syariah tersebut sistemnya masih sama dengan Bank Konvensional.

Konten yang disediakan aplikasi untuk para penggunanya adalah
- Sejarah bank syariah,
- Layanan m-Banking,
- Jenis-jenis tabungan
- Syarat-syarat KPR
- Syarat-syarat KURS
- Dasar hukum Bank Syariah
- Simulasi KPR dan untuk informasi aplikasi Bank Syariah
- Konten Call Center yang terdiri dari 12 Bank.

\section{Profil Responden}

Uji coba aplikasi ini berlokasi di Yayasan Baitul Yataama Fadlan. Nama Ketua Yayasan Nur Hendra, Tahun berdiri : 2011, Legalitas : AHU-07525.50.10.2014 dan memiliki karyawan 83 orang. Karyawan terdiri dari 45 karyawan tetap dan 38 penjemput yatim. Yayasan berlokasi di Jl. Arthayasa Blok Tengki 1 RT 03/10 Kel. Meruyung Kec. Limo Kota Depok Jawa Barat. Adapun responden adalah karyawan tetap terpilih dengan profil sebagai berikut: 
Tabel 1

Profil Responden

\begin{tabular}{|c|l|c|c|}
\hline No & \multicolumn{1}{|c|}{ Lokasi } & Jumlah & $\begin{array}{c}\text { Rata-rata } \\
\text { Usia }\end{array}$ \\
\hline 1 & $\begin{array}{l}\text { Gedung } \\
\text { Pusat }\end{array}$ & 11 & 22 Tahun \\
\hline 2 & $\begin{array}{l}\text { Gedung } \\
\text { Pendidikan }\end{array}$ & 10 & 21 Tahun \\
\hline 3 & $\begin{array}{l}\text { Gedung } \\
\text { Aula }\end{array}$ & 13 & 22 Tahun \\
\hline
\end{tabular}

3. Hasil Uji Pengetahuan Responden Sebelum Dan Setelah mempelajari Aplikasi

Dari 34 orang yang responden terpilih, kemudian diminta untuk menjawab pendapat mereka pada lembar kuesioner. Kuesioner terdiri dengan pertanyaan yang berjumlah 12 pertanyaan, dan dikelompokan menjadi 4 yaitu tentang pengetahuan bank syariah, pengetahuan Tabungan, pengetahuan layanan, pengetahuan pinjaman dan pengetahuan hukum perbankan syariah. Jawaban responden dikelompokkan menjadi jawaban mengetahui atau tidak mengetahui atas pertanyaan yang diajukan. Hasil uji pengetahuan yang di peroleh menunjukan bahwa rata-rata usia responden adalah 19-20 tahun. Mayoritas responden tidak mengetahui secara detail tentang Bank Syariah, dikarenakan kurangnya pengetahuan dari lingkungan, tidak pernah transaksi di Bank Syariah dan faktor pendidikan yang tidak mempelajari tentang Bank Syariah.

Tabel 2

Hasil Survey Di Gedung Pusat Jumlah Responden Menjawab Mengetahui

\begin{tabular}{|c|l|c|c|}
\hline No & \multicolumn{1}{|c|}{ Keterangan } & Tes 1 & Tes 2 \\
\hline 1 & $\begin{array}{l}\text { Pengetahuan Bank } \\
\text { Syariah }\end{array}$ & 11 & 11 \\
\hline 2 & $\begin{array}{l}\text { Pengetahuan } \\
\text { Tabungan }\end{array}$ & 2 & 6 \\
\hline 3 & Pengetahuan Layanan & 9 & 11 \\
\hline 4 & Pengetahuan Pinjaman & 1 & 3 \\
\hline 5 & Pengetahuan Hukum & 1 & 4 \\
\hline \multicolumn{2}{|l|}{ Rata-Rata } & 4,8 & 7 \\
\hline \multicolumn{2}{|l|}{ Persen dari total responden } & $43 \%$ & $64 \%$ \\
\hline
\end{tabular}

Tabel 3

Hasil Survey Di Gedung Pendidikan Jumlah Responden Menjawab Mengetahui

\begin{tabular}{|c|c|c|c|}
\hline No & Keterangan & Tes 1 & Tes 2 \\
\hline 1 & $\begin{array}{l}\text { Pengetahuan Bank } \\
\text { Syariah }\end{array}$ & 10 & 10 \\
\hline 2 & $\begin{array}{l}\text { Pengetahuan } \\
\text { Tabungan }\end{array}$ & 7 & 10 \\
\hline 3 & Pengetahuan Layanan & 10 & 10 \\
\hline 4 & Pengetahuan Pinjaman & 3 & 6 \\
\hline 5 & Pengetahuan Hukum & 1 & 4 \\
\hline & Rata-Rata & 6,2 & 8 \\
\hline \multicolumn{2}{|c|}{ Persen dari total responden } & $62 \%$ & $80 \%$ \\
\hline
\end{tabular}

Tabel 4

Hasil Survey Di Gedung Aula Jumlah Responden Menjawab Mengetahui

\begin{tabular}{|c|c|c|c|}
\hline No & Keterangan & Tes 1 & Tes 2 \\
\hline 1 & $\begin{array}{l}\text { Pengetahuan Bank } \\
\text { Syariah }\end{array}$ & 10 & 13 \\
\hline 2 & Pengetahuan Tabungan & 4 & 8 \\
\hline 3 & Pengetahuan Layanan & 8 & 10 \\
\hline 4 & Pengetahuan Pinjaman & 3 & 6 \\
\hline 5 & Pengetahuan Hukum & 0 & 2 \\
\hline & Rata-Rata & 6,2 & 8 \\
\hline \multicolumn{2}{|c|}{ Persen dari total responden } & $48 \%$ & $62 \%$ \\
\hline
\end{tabular}

\section{Pembahasan}

Tabel 5

Hasil Survey di Seluruh Gedung Jumlah Responden Menjawab Mengetahui

\begin{tabular}{|c|c|c|c|}
\hline No & Keterangan & Tes 1 & Tes 2 \\
\hline 1 & $\begin{array}{l}\text { Pengetahuan Bank } \\
\text { Syariah }\end{array}$ & 31 & 34 \\
\hline 2 & Pengetahuan Tabungan & 13 & 24 \\
\hline 3 & Pengetahuan Layanan & 27 & 31 \\
\hline 4 & Pengetahuan Pinjaman & 7 & 15 \\
\hline 5 & Pengetahuan Hukum & 2 & 10 \\
\hline & Rata-Rata & 16 & 22,8 \\
\hline \multicolumn{2}{|c|}{ Persen dari total responden } & $47 \%$ & $67 \%$ \\
\hline
\end{tabular}

Dapat dilihat bahwa aplikasi edukasi perbankan syariah berpengaruh signifikan dalam meningkatkan pengetahuan karyawan Yayasan Baitul Yataama Fadlan, dari hasil tersebut dalam ditunjukkan bahwa hasil survey pertama sebesar $47 \%$ dan hasil survey 
kedua sebesar $67 \%$. Terdapat kenaikan prosentase responden yang menjawab mengetahui perbankan syariah sebesar $20 \%$.

Atas hasil tersebut di atas maka hasil dari hipotesis adalah aplikasi edukasi perbankan syariah $(\mathrm{X})$ berpengaruh signifikan terhadap peningkatan pengetahuan karyawan (Y).

Berdasarkan hasil pengamatan selama periode penelitian dan jawaban kuesioner responden, ada beberapa faktor yang menyebabkan Karyawan Yayasan Baitul Yataama Fadlan kurang mengetahui tentang perbankan syariah :

1. Berdasarkan hasil dari data kuesioner yang sudah penulis teliti, bahwa tingkat pengaruh umur berpengaruh terhadap pemahaman responden terhadap pengetahuan perbankan syariah.

2. Lingkungan juga berpengaruh terhadap pemilihan responden untuk menggunakan Bank Syariah atau pun Bank Konvensional.

3. Tingkat Pendidikan responden juga sangat berpengaruh terhadap pengetahuan dan informasi-informasi Bank Syariah.

4. Dari data yang di dapat dari hasil kuesioner dijelaskan bahwa masih banyak yang tidak tau dengan sistem serta keunggulan-keunggulan yang terdapat di Bank Syariah.

Kegiatan peningkatan literasi dengan menggunakan aplikasi berbasis android ini merupakan kegiatan yang inovatif. Pengguna akan lebih nyaman, karena aplikasi menyediakan fitur untuk kemudahan dalam membaca dan disajikan dengan tampilan menarik. Tampilan menarik bisa menarik minat masyarakat untuk mempelajari dan kemudahan yang disediakan dapat membantu pengguna untuk mendapatkan konten yang diinginkan. Sehingga meningkatkan pengetahuan. Hal ini selaras dengan penelitian Adha (Adha, Saputri, \& Hannah, 2018) yang menganalisa efektifitas penggunaan web base learning pada mata kuliah praktikum struktur data, hasil penelitian menunjukkan terdapat efektifitas dalam pembelajaran dan meningkatkan hasil pembelajaran.

\section{KESIMPULAN}

Dari hasil penelitian kesimpulan yang dapat diambil yaitu masih kurangnya pengetahuan Karyawan Yayasan Baitul Yataama Fadlan tentang perbankan syariah, sehingga menyebabkan mereka tidak berminat untuk membuka tabungan atau melakukan transaksi di Bank Syariah.

Hasil survey pertama menggunakan kuesioner menunjukkan hasil sebesar $47 \%$. Responden men download aplikasi pada Playstore dan instal pada telephon genggam. Responden diberikan waktu 2 hari untuk mempelajari aplikasi tersebut. Selanjutnya dilaksanakan survey kedua dengan hasil sebesar $67 \%$. Terdapat kenaikan prosentase responden yang menjawab mengetahui perbankan syariah sebesar $20 \%$. Hal ini dapat disimpulkan bahwa Aplikasi edukasi perbankan syariah berpengaruh signifikan dalam meningkatkan pengetahuan karyawan Yayasan Baitul Yataama Fadlan.

\section{DAFTAR PUSTAKA}

Adha, N., Saputri, O., \& Hannah, M. P. (2018). Analisis Efektifitas Penggunaan WebBased- Learning pada Matakuliah Praktikum Struktur Data. JUST IT: Jurnal Sistem Informasi, Teknologi Informatika Dan Komputer, 8(2), 69-75.

Azhar Muttaqin, D. A. D. (2017). Kualitas Produk, Pelayanan dan Nilai Syariah terhadap Persepsi Mahasiswa Ekonomi Islam untuk Menjadi Nasabah Bank Syariah. FALAH: Jurnal Ekonomi Syariah, 2(2), 196.

Febriani, A., \& Hidayati, N. (2017). Penerapan Aplikasi Program Penjualan Dan Pembelian Menggunakan Model Rapid Application Development. Jurnal Informatika, 4(2), 261-271.

Ghofur, A. A. (2018). Perbankan Syariah Di Indonesia. Yogyakarta: Gadjah Mada University Press.

Iskandarsjah, E. (2017, December 18). Pemahaman Masyarakat tentang Perbankan Syariah Masih Minim. Https://Www.Republika.Co.Id. 
Misbahudin, I. H. (2013). Analisis Data Penelitian Dengan Statistik. Jakarta: Bumi Aksara.

Mulyadi. (2013). Android App Thunkable. Yogyakarta: Multimedia Center Publisting.

Rachman; Adi Fida. (2015). Android Kuasai Asia Tenggara, di Indonesia Paling Juara. Detik.Com.

Rusydiana, A. S. (2016). Analisis Problem Pengembangan Perbankan Syariah Di Indonesia: Aplikasi Metode Analytic Network Process. Esensi, 6(2), 237-246.

Septyaningsih, I. (2018, December 8). Penyebab Perkembangan Bank Syariah di Indonesia Lambat. Https://Republika.Co.Id.

Supardi; Yanuar. (2015). Belajar Coding Android Bagi Pemula. Jakarta: PT Elex Media Komputindo.

Supyadillah; Asep. (2013). Hukum Perbankan Syariah. Jakarta: Wahana Kardofa. 